\title{
The New Plan for the Prevention of School Failure in Catalonia (Spain)
}

\author{
Núria Llevot Calvet ${ }^{1}$ - Juan Agustín González Rodríguez ${ }^{1}$ \\ Alfonso Revilla Carrasco ${ }^{2}$ \\ ${ }^{1}$ Universitat de Lleida - Departament of Pedagogy and Psychology (Spain) \\ ${ }^{2}$ Universidad de Zaragoza - Departament of Musical, Plastic and Body Expression (Spain)
}

doi: 10.7358/ecps-2016-013-llev

nllevot@pip.udl.cat

agustin.gonzalez@pip.udl.cat

alfonsor@unizar.es

IL NUOVO PIANO PER LA PREVENZIONE

DELL'INSUCCESSO SCOLASTICO IN CATALOGNA (SPAGNA)

\section{Abstract}

This paper outlines the development of the Ministry of Education's Compensatory Education Program focusing on the changes in Catalonia due to the Plan for Language and Social Cohesion. This program was the emblematic result of the reformist policy adopted in 1983 in the field of education. It was, therefore, a hopeful and optimistic discourse aimed at correcting social inequalities and producing higher levels of social justice. Despite the inherent weaknesses of this approach, the Compensatory Education Program has enabled carrying out interventions in particularly complex areas and, in addition, the range of activities has been very broad and ambitious. Currently, its disappearance and transformation poses a challenge to the government to address the education of ethnic minorities at risk of social exclusion as well as actions to promote school success, to reduce school failure (scheduled for 2018). The development of Education's Compensatory Education Program will be useful to students of foreign origin in order to improve their academic opportunities and of continuing in the education system.

Keywords: Compensatory, Educational policy, Immigrants, Language and school failure, Schools. 


\section{Creation And DeVelopment OF THE COMPENSATORY EdUCATION PROgRAM}

In Spain, compensatory education began in 1983 (Royal Decree of April 27, 1983 , BOE $05 / 11 / 1983$ ), with the creation of a specific program that sought to provide preferential educational services in those geographical areas or population groups whose special characteristics so required. The actions primarily to be carried out by the new program included (CIDE, 1992): the creation of support services situated at the resource centers located in preferential areas of educational action for school aid; the encouragement of the continuity of teachers assigned to difficult-to-cover vacancies; the organization of vocational training courses for out-of-school youths between fourteen and fifteen years of age; the eradication of illiteracy and the creation of specific study modalities.

In general, the Spanish project, issued by Minister Maravall during Felipe González's first socialist government, was directly inspired by the British Labour Party's controversial experience of the Educational Priority Areas ${ }^{1}$.

In a broad sense, Muñoz Sedano (1989) refers to compensatory education policy, i.e. positive discrimination political, economic and social actions, as well as those related to schooling, applied to an economically, socially and culturally impoverished population, to boost the reduction and elimination of disadvantages in the education system. During the 1987-1988 academic year, a total of five programs were implemented in Spain as part of the previously mentioned global program in which we highlight the Cultural Minorities Program because of the different socio-cultural system and the uprooting that it involves. Therefore, any attempt at the schooling and support of a person must always take into account their peculiarities (nomadism, high degree of mobility of these group, etc.) (CIDE, 1992).

In Catalonia, the circular of September 15, 1988 addressed to schools with students at risk of social marginalization, set out the existence of the Program of Compensatory Education for Social Outcasts by the Catalan Department of Education which would look after underschooled students motivated by Department of Education (1988):

- Late registration: children who have enrolled for the first time over the age of seven (or more than five if they do not know any Catalan and/or Spanish at all).

1 Samper, Llevot, Garreta, \& Chastenay, 2002: educational policies of compensatory education implemented in the United States since the end of 1950 and in the UK in the 1960s from notions such as cultural deprivation or linguistic deprivation, applied indistinctly to pupils of working class origin or from ethnic minorities were questioned by both conservative sectors of opinion and by the new sociology of education; see Bernstein, 1971. 
- High absenteeism: when truancy caused by a nomadic family or other very specific reasons exceeds fifty days per school year.

- Run-down living and housing conditions: ghettos, slums, etc.

The aim was to ensure schooling was as standardized as possible, with suitable integration. To help achieve this, the program provided educational support to basic education teachers with resources and classroom materials and, if possible, social support to families through social workers and some aid that favored schooling (school meals, educational materials, school trips and excursions). When it was created, during 1983-1984 (Jordan, 1992), provisionally and with three seconded teachers, it attended to gypsy children from the neighborhood of Perona, in Barcelona and it gradually grew larger: - The programs were: support program in rural areas, projects at support centers for out-of-school youths, cultural minorities and the traveler population (CIDE, 1992).

- The concept included students at risk of marginalization who had problems of personal maturing, habituation and socialization, as well as difficulties related to motivation and continuity in learning due to their sociocultural background.

However, totally beyond the scope of the Social Outcasts Program were those students with special education needs, characterized by bad behavior, absenteeism caused by problems unrelated to the marginalization, etc.

Later, the scope was extended to other areas of Barcelona city (Raval, Ciutat Vella ...) to other cities of the province (Santa Coloma de Gramenet, Sant Adrià del Besòs, Santa Perpètua de Mogoda, Sabadell, Cerdanyola del Vallès, etc.), Tarragona (Reus, Tortosa ...) and Girona (Figueres, etc.) (Jordán, 1992, pp. 174-175).

A few years later, on December 19, 1990, Javier Solana, the minister of the Ministry of Education and Culture, together with Josep Laporte, the Catalan Education Minister, signed a collaboration agreement with respect to compensatory education in which the Department assumed the implementation of actions in Catalonia. The main goal of the Program of Compensatory Education for Social Outcasts (Montano, Castile, \& Perez, 1992) was to support the full educational integration of students excluded socially because of either economic, cultural and/or ethnic reasons.

The main issues for the integration of these students (Social Welfare, 1994) - primarily gypsy and Arab - detected by the program through the information and the collaboration of tutors and teachers served to provide solutions specified in two levels (Tarragona/Lleida Compensatory Education Program, 1994) as summarized in the Table 1 (Llevot, 2005). 
Table 1 .

RELATED WITH CHILDREN

\begin{tabular}{ll}
\hline \multicolumn{1}{c}{ Arab children } & \multicolumn{1}{c}{ Gypsy children } \\
\hline $\begin{array}{ll}\text { - Lack of knowledge of the languages } \\
\text { of learning. }\end{array}$ & $\begin{array}{l}\text { - Different attitudes and expectations } \\
\text { regarding the educational institution. }\end{array}$ \\
$\begin{array}{ll}\text { - Gap between the command of the vehicular } \\
\text { language and the language of learning. }\end{array}$ & $\begin{array}{l}\text { - Lack of social habits (order, cleanliness, } \\
\text { punctuality, etc.) that constitutes } \\
\text { an obstacle to integration into regular }\end{array}$ \\
$\begin{array}{l}\text { - No match of the student's level of school } \\
\text { learning and their educational level. }\end{array}$ & schools. \\
- Limitations in the relationship & - Lulture based on oral tradition. \\
between family and school. & - Systematic absenteeism. \\
- Families with an economic level & - Dropping out of school at 11/12 years old. \\
and living conditions in the context & - Late schooling (as of 7 years old). \\
of marginalization, not very different & - High percentage of school failure. \\
from the rest but always a step below & \\
because they are immigrants. & \\
- Culture clash. & \\
- Problems to process the academic & \\
documentation due to the delay linked & \\
to getting hold of the academic & \\
documentation from the country of origin. & \\
- Linguistic interference. & \\
- Laterality problems.
\end{tabular}

RELATED WITH EDUCATIONAL INSTITUTIONS

- Adaptation or rejection of these students to school and to diversity in general.

- Difficulties to provide the individualized attention students require (at least in the early school years), caused by not having enough human resources and not having enough resources to make organizational changes in the management of the centers.

- Need to establish coordination with the school and the family that goes beyond economic links.

- Lack of training and guidance for teachers to manage cultural diversity in the center, both regarding methodological aspects and cultural awareness.

All these requirements were specified in a number of guidelines and actions (Department of Education, 1996b) that were developed for all teachers and social workers pertaining to the Compensatory Education Program (CEP) of the Catalan Government:

- With regard to the school guidelines concerning the education of children at risk: the foundations for appropriate integration, recommendations for registration and entrance to the course, academic documents for the rel-

\author{
ECPS Journal - 13/2016 \\ http://www.ledonline.it/ECPS-Journal/
}


evant registration and recognition of qualifications, contacting and assisting families, suggestions for the entry of the child in the classroom, class group relations, providing a list of materials and resources to have in the classroom. In the case of Arab children, ascertaining their level of language ability, instructions for the teaching of the language of learning and preventing the main added difficulties (when initiating literacy: laterality, directionality, handwriting ...) as well as respect for and understanding of their culture.

- With respect to activities or lines of work of the professionals: advise the schools these students attend, develop educational materials tailored to the needs of the pupils, offer items of information and training to tutors and teachers who work with them, monitor and prevent situations of absenteeism and dropout, ensure the financial support (books, school dinners ...) that promotes regular attendance in class and monitor the students.

This program, after first-aiding the centers for a while, had to reorient its task; firstly, because no one can replace the obvious lack of resources (material, human and organizational) that schools have and, secondly, because actions from the outside are useless by themselves if the institutions do not change and neither do the people who belong to them (with the attitudes, evaluations, etc.). In fact, during the 1993-1994 academic year, restructuring took place, not without tensions, divisions and difficulties which seriously jeopardized the continuity of the program, which caused the flight of a considerable number of members to their final destinations ${ }^{2}$. One such example was the abandonment of the creator and coordinator of the program due to misunderstandings with the director general regarding the orientation of the working plan, as he explains in an interview, in which he recounts the beginning of it:

From the Department of Education, the then General Director (Joan Girona), who died last year, asked me to run the Compensatory Education Program. This program was created to help schools which incorporated gypsy people. At the same time, the schools of El Camp de la Bota and La Perona disappeared, hence, the gypsy pupils had to go to regular schools.

At that time, the program was called Integration because it tried to prevent gypsy ghettos and then the Compensatory Education Program began to help those schools which had gypsy people for the first time: to help them integrate and change from a school solely for gypsies to a mixed one. [...] the sixth year, we had a disagreement with the new director general (Joan Girona). The director was in favor of the Compensatory Education Program practically to merge with the EAP and so the idea started to emerge, which is unfortunately still

2 See Grup FUS, 1999. 
accepted, that students [...]. Gypsies and immigrants are different, but they are pupils with special educational needs and, therefore, the EAP were already $\mathrm{OK}$, right? and, so, she also wanted that, in addition to compensatory, they be assigned to EAP. Because I didn't agree with it, I quit at the end of year [...].

\section{POLITICS AND THE INTEGRATION OF IMMIGRANT STUDENTS IN CATALONIA}

The Spanish education system is undergoing a process of change, among other reasons motivated by a desire to make it more competitive, more modern, better positioned in international rankings and ultimately improve its excellence without forgoing quality. All this leads us to recognize how vast the experience of our formal education system reforms and legislative changes was throughout the twentieth century. In fact, since 1970 when the Education Act was promulgated, various reforms have been implemented, with varying degrees of success and permanence which have granted our schools their own character. The Organic Law of Education Quality Improvement ${ }^{3}$ came into force on January 3, 2014 although the reform will begin to be implemented in the 2014-2015 academic year, a proposal that could be a very good reason and even an opportunity to review what has been formulated to date with one of the major challenges of our education, namely, attention to immigrant students. Almost at the same time, the debate on the alleged need to replace the subject of Education for Citizenship with another training exclusively in values also emerged ${ }^{4}$. The change was finally made, but without explaining the possible improvements that this will involve to avoid failure and dropout, which are so rife in our education system.

Since the economic crisis there has been greater commitment to the significant increase in certain actions at local level and greater coordination in the design of policies and actions by each regional government toward the groups at risk of social and cultural exclusion and this is reflected in the strategic initiatives in Catalonia.

We still need to determine the uncertain future envisaged with the current LOMCE because we do not know whether it will decide for an inclusive, participatory, equitable and democratic educational model ... or, on the

3 It was passed in Parliament on November 28, 2013. This is a controversial law that has been questioned by certain social and political sectors-indeed during its passage through Parliament it was not supported by any other parliamentary group except the People's Party.

4 Social and Civic Values in primary school and Ethical Values in secondary school. In baccalaureate Religion will become part of the specific optional subjects, both in 1st and 2nd years. 
contrary, will it become selective, competitive, meritocratic, exclusive and segregating for those students who fail to meet standards of quality, now conceived as excellence.

Also one of the fiercest debates that occurred between regional education ministers and the Spanish minister has dealt with respecting the co-official languages, especially in the case of Catalonia. The legislation, as already recognized by the Spanish Minister of Education, Culture and Sport, José Ignacio Wert repeatedly, seems tailor-made for Catalonia. In principle, it forced communities to fund the private school of those parents wishing to enroll their children with Castilian Spanish as the vehicular language. And months after approving this issue, a compromise amendment was passed by UPyD in which the text was changed to toughen it further. All the above are issues that are hardly compatible with a model of language immersion, like the one in Catalonia or the recently amended one in the Balearic Islands, which managed to get its students to achieve good results for Spanish in international reports, despite teaching most of the subjects in Catalan.

When, at the beginning of 1981 (BOE 31/12/1980) education matters were transferred to the Catalan Government, the current organizational structure got under way. And although years ago the Compensatory Education Program ${ }^{5}$ had been developed, in 2003 the Catalan Education Department drafted the Action Plan for Schoolchildren of Foreign Nationality 2003-2006 (PAANE) as a result of the National Conference on Education 2000-2002 whose Section III, on Support for Diversity, includes suggestions and proposals for improvement of the education system. This Plan primarily considered aspects of language learning without taking account of other fundamental aspects of reception, such as emotional, relational and social cohesion that affect all students. Aware of this, the Department prepared a new document and so the 2004 Plan for Language and Social Cohesion, within the framework of the Interdepartmental Immigration Plan, was approved. That year, the Subdirecció General de Llengua $i$ Cohesió Social was created in the Department, by Decree 282/2004, with the aim of ensuring equal opportunities for access to quality education, respecting cultural diversity and strengthening Catalan as the axis of a multilingual educational project based on the values of coexistence, equality and social and educational inclusion of all pupils. The Subdirecció General had two administrative units: the Servei Català d'Ensenyament (SEDEC) and the Servei d'Interculturalitat $i$ Cohesió Social (SICS) that, coordinatedly, wanted to boost the Plan for Language and Social Cohesion in the regions. To carry out the different actions they had a team to reinforce language, multiculturalism and social cohesion (LIC).

5 See Llevot, 2005. 
This has been concretized (Garreta, 2011a) with the development of plans for the reception and integration of all students, the design of the language project, the development of intercultural education, the creation of reception classrooms and School Adjustment Workshops (TAE) and the boosting of Community Education Plans (PEE) ${ }^{6}$ and the training of professionals in the centers with classes teaching foreigners.

Article 10 of the Education Act of Catalonia (LEC) of July 17, 2009 develops the right and duty to know the official languages since, as Article 11 says, it is the vehicular language and the language of learning in Catalonia. Thus, educational activities (oral and written), teaching materials, textbooks, assessment activities in all areas, subjects and curriculum modules should be prepared and taught in Catalan generally, except for the subjects Spanish and foreign language and literature.

Therefore, intervention with foreign students, by means of Decree 297/2011, of March 22, on the restructuration of the Department of Education, is managed by the Secretaria de Politiques Educatives, more specifically within the Subdirecció General de Llengües i Plurilinguisme.

Consequently, the Department, in accordance with the principles and objectives set out in the LEC and the plan of action established in the "Acord marc per lluitar contra el fracàs escolar» (framework agreement to fight against school failure) of February 8, 2011 of the Catalan Government, developed the Plan to Reduce School Failure (Department of Education, 2013) ${ }^{7}$ to wage a campaign for school success in six years (2012-2018) with four major objectives: to improve the skills of primary education students, increase the skills level of students in compulsory high school education (hereafter ESO), increase the academic achievement of students of ESO, and reduce the rate of early school leaving.

This Plan presents ten main lines of action: (1) Professionalization of teaching; (2) Attention to student diversity and customization of teaching;

6 As a support network for the educational community with the collaboration of the various municipal services and resources and other regional social, cultural and sporting institutions or entities. It aims to contribute to the educational success of all students.

7 The Catalan Education Minister submitted on June 28, 2012 to the Comissió d'Ensenyament i Universitats of the Catalan Parliament the Plan entitled «Country-wide campaign to reduce school failure in Catalonia 2012-2018». This proposal emerged to respond to a problem of our educational environment that has serious personal and social consequences, and sets the goal of halving school failure within a period of six years, as embodied in specific goals in relation to the skills level of the students, academic performance and dropout rate. The different projects are developed by regional Directorates General and Services within the framework of other plans and programs that respond to the common goals of the education system. 
(3) Promotion of reading; (4) Methodological and didactic innovation in the classroom; (5) Multilingualism; (6) Autonomy of the center; (7) Professionalization of school management; (8) Involvement and commitment of the family; (9) Relations between the educational community and the environment; (10) Decreased absenteeism and dropout.

Within these axes, from the 2012-2013 school year planned up to 2017-2018, we highlight the measures in relation to socio-cultural diversity:

- Community Education Plans (PEE) with joint responsibility of municipal entities and the different regional agents.

- Intensive Improvement Program (PIM) aimed at students who start first year of ESO and have generalized learning difficulties leading to the reinforcement of basic skills in languages and mathematics for one school year.

- Protocols for action and individualized plans for students at risk of sociocultural marginalization.

- Training and guidance for schools and teachers on issues of multiculturalism and social cohesion by support teams and advice on language, multiculturalism and social cohesion (ELIC).

- Virtual courses with materials, resources and guidance on the reception of newcomer students, care for their families, the teaching of Catalan as a second language, learning activities, language intervention strategies ...

- Provisions of reception classes in primary and high school, considered open environments, to help resolve the concerns of teachers providing immediate support and ensuring language learning and its progressive incorporation into the regular classroom.

- Coexistence projects addressing seventeen subjects concerning co-habiting grouped in three areas: values and attitudes, conflict management, and center management, which are worked on in the classroom, in the center and in the community so as to give educational continuity and coherence to the different actions.

- Creating a family-school website to inform about and guide families during the educational process and their relationship with the center.

- Learning communities as a project based on a set of successful educational activities aimed at social and educational transformation. This model is consistent with scientific theories, at international level, that highlight two key learning factors in today's society: interactions and community involvement.

- Second chance pilot projects ${ }^{8}$ for young people aged 16 to 18 .

8 Carried out, during 2012-2013, through an agreement with foundations El Llindar and Cassià Just in Cornellà (Barcelona). 
- Project for the promotion of the gypsy people ${ }^{9}$ in order to reduce absenteeism and dropout by these students and enhance the visibility and values of their culture within the curriculum and the center. Given the high percentage of gypsy students from Romania in the centers, the hiring of two figures is considered: the translator (for language interpretation) and the school promoter (mediator for the prevention and management of conflicts).

\section{THE LONG PROCESS OF EVOLUTION TOWARD INTERCULTURAL EDUCATION}

As time passes, the PEC officials have changed their direction and it is clear that the official discourse has always been in the "development phase». Its application was in response to different levels (Palaudarias, 1998): school (direct actions and contributions of specific materials, many produced by the Compensatory Education Program team), tutors (training and information to address the problems that arise in the classroom), faculty (sessions to promote a climate of acceptance of students' particularities), actions by areas (together with other services and educational programs, as well as social services), materials and content adaptation (modifying or adapting curricula) and teacher training (courses provided through the Department's training plan to initiate awareness in these issues).

The program has also participated in a project of the European Commission's Socrates Program called Comenius II9, based on transnational intercultural education projects. Actions have been carried out with support for immigrants from Arab countries and the promotion of intercultural education. (Department of Education, 1996)

Analyzing in greater depth the orientations of this program, in the 19992000 academic year, in terms of interventions and activities at schools we can see:

\section{a. The centers involved}

The PEC is not involved in all educational institutions (of primary and high school) that receive immigrant students, but in schools that have completed a formal application usually by means of the Inspection Office, which,

9 In collaboration with the Fundación Privada Pere Closa and the Fundación Secretariado Gitano - Gypsy Secretariat Foundation. 
taking into consideration the proposals of the professionals of the program, will decide what will be worked on during that academic year. Timely and regular support actions are established, leaving a few hours a week for other bureaucratic tasks and unexpected problems. Given the large number of schools opting for this service, those receiving immigrants for the first time are considered preferential. Therefore, it is common for PEC teachers not to go to the same school every year.

The number of schools attended by the PEC varies according to the guidelines issued by the Department. When it was established, it sought to respond to all requests, but then program assistance was considered only a «troubleshooter» so, since the 1998-1999 academic year, it has been limited to a certain number of schools (although there are others to which it would be appropriate to go). The average number of regularly visited centers is about ten: in the morning five regular ones, and in the afternoon, five more timely. Two afternoons are left free for new demands and the preparation of materials. These changes reflect a new direction for the program:

At the beginning, the PEC focused its performance on direct attention to new students. Tutors and faculty positively valued this support because they are fast learners, like sponges, but they need individualized attention that the school could not assume [...].

Then, we tried to reorganize the intervention giving more weight to guidance and advice, with the aim that the centers would assume the new situation. Although PEC teachers valued positively the direct contact with students of immigrant origin, this work took many hours and reduced the time the teachers had to prepare programs and look after coordination, which were in fact the actions that served to spread interculturality in school (as the coordinator of Compensatory Education Program in Lleida tells us). But actually, members of the PEC just end up subtracting direct attention in many cases. (Crespo, 1997, p. 646)

The distribution of the centers among PEC professionals corresponds to each regional delegate (or the person in whom this is delegated).

When applying it, the previous experience or the professional's specialization in infant, primary or high school education, and the number of years a professional attends at the same school, considering the timing criteria.

\section{b. Actions at centers}

The purpose of the PEC is to work with schools and teachers in the educational integration of pupils at risk of social exclusion and/or foreign students with special educational needs associated with adverse social or cultural situations, with difficulty to access, remain and progress in the education system (prioritizing primary and those starting the first cycle of

\footnotetext{
ECPS Journal - 13/2016

http://www.ledonline.it/ECPS-Journal/
} 
compulsory high school). The work of the teachers and social workers must allow these students to receive an appropriate response to their needs. This involves collaboration with centers with respect to the monitoring of those students who can present difficulties in the transition from primary to high school, the reception of newcomers, temporary direct support to those who need it, help in different organizational forms to meet classroom diversity, the adaptation of teaching materials, the proposal of strategies and activities to promote cultural diversity and other issues of a similar nature at the center. Direct attention to centers involves, at least, twenty-four hours per week (allocated preferably during all the mornings and three afternoons). On the other hand, this kind of attention requires cooperation with the educational programs and services of the Department, as well as consulting with employees from other departments.

In particular, what must be taken into consideration is the joint work with psychologists assigned to high schools with the professionals of the Educational Psychology Assessment Teams (EAP) and the Catalan Teaching Service (SEDEC) involved in the schools themselves, in order to combine the actions related to students who must be attended to and the measures to attend to diversity to achieve maximum consistency in proposals.

The development of a particular program was agreed and signed by the center management together with PEC professionals. Their work plan refers to schools (reception plan and schooling, guidance and information for schools, families and students) and the social environment (truancy and mediation programs). When first proposing actions in schools, the program always does so provisionally and the activities are specified for a maximum of three consecutive years, depending on the agreed objectives. If the factors that caused intervention remain at the end of the three years, each year may evaluate whether to carry on for another and, if necessary, the action can be extended.

The PEC has progressively been getting more specific regarding its first orientations and priorities which, lately (Department Education, 1999), had resulted in:

One. Priority areas for teacher action. To collaborate in actions related to the reception of students (providing information and guidance on cultural differences, engaging in observation and needs detection, providing criteria for relations with families, ensuring good relations with classmates, cooperating with actions aimed at preventing truancy and easing the transition from primary to high school); to attend to students directly (depending on the needs detected, with preparatory work with the tutor and when deemed relevant, individually, in a small group, with the class or any other type of group), 
to provide guidance to teachers on the learning of Catalan by foreign students (according to SEDEC criteria, provided that intervention by the corresponding advisors is not possible), to provide educational materials adapted to needs (without being disconnected from the rest of group activities), to collaborate in the realization and implementation of optional reinforcement subjects (according to the center's support for diversity committee), to help with the management of financial aid (referring to books, teaching materials and school meals), and to promote intercultural education in the school (suggestions, monitoring and systematic review of the activities).

Two. Plans of action by social workers. To meet the families of students at risk of marginalization (in order to guide them in the process of enrollment, in the corresponding procedures, improve relations with the institution), to cooperate with the schools and social services in relation to students with high absenteeism and dropout rates (especially in the design and undertaking of actions to promote progressive participation), to collaborate and ensure the implementation of school health programs (specifically those which refer to pupils and their families to improve hygiene, food and health-related preventive issues), to collaborate and manage the processes of economic aid (reference books, educational material and school meals), to coordinate with EAP social workers (to complement and provide continuity to the interventions derived from the social areas).

Three. As far as training professionals is concerned, those of the PEC can participate in the continuous training activities provided to teachers in the area, in which they are involved in the same conditions as the other teachers, even though they will have a specific training plan to ensure the proper performance of the functions assigned. Especially, intervention in high school cannot be based on the willingness of the professionals or the personal and professional experience of each individual. In this sense, up to the1998-1999 academic year contradictions arose (Compensatory Education Program, 1998), such as:

- Interventions by people who were not necessarily accredited to go there.

- Besides, this action was not accompanied by any recognition regarding such issues as schedules, economic equality, merits or others.

These two facts meant that they often performed a contingency task in response to the most pressing needs of the students, and a few (superficial and anecdotal) intercultural elements were introduced.

All in all, the draft on Education and Immigration from outside the EU, by the FUS Group (1999) showed the trajectory of this program and it was considered that it should be established as a reference for preventing 
social exclusion and tackling cultural diversity in the school. But, to do so, this group believed that some changes had to be made:

- First, change the name for a more complete and less segregating one, for example, they opt for the Education Service for Equal Opportunities and Intercultural Education (SEIO).

- Consolidate the program as a permanent service to ensure more professionalism and interest on the part of the professionals working in it.

- Define and specify the lines, orientations and tasks for all the delegations of the program, despite being adaptable to each region.

- Enhance recycling and specialization tracks for the professionals working in it.

- Distribute the professionals according to needs and assess the results from different perspectives.

According to Carbonell (2000), this program should refocus its line of work and action in order to establish itself as a framework of reference for preventing social exclusion and tackling diversity in educational institutions, and abandon the temporality and the decadence in which it has always been immersed, as well as the professionalism and specialization of the people working there (as mentioned before, often more interested in administrative positions - not moving to a particular town, city or neighborhood - than in the goals of the program).

This, together with the continuous criticism of these professionals, the increase of students at risk of social and cultural marginalization in educational institutions, etc., led to the creation (1990) of the Compensatory Education Program attached to the Special Education and Educational Programs Service, in order to advise and support centers to prevent any form of social exclusion and promote intercultural education among students.

A recent document published on that period, by the Department of Education $(2004,2007)$, cites the reorientation of the program for the next millennium, quoted literally in other documents:

[...] the aim of this intervention is to involve young children in school, normalizing their attendance and reducing their rate of descent, accommodating the characteristics of each cultural group. [...] Compensatory education responds to the inequality of opportunities suffered by some groups in the education system due to various factors (social, economic, cultural, geographical, ethnic ...). It is considered necessary to ensure some minimum standards in education. It consists of implementing complementary actions in certain schools (at their request and under the supervision of the Education Inspectorate) to reduce inequalities, adopt preventive measures, which would best be carried out during the early years of schooling. (Department of Education, 1999, pp. 7-8) 
The teaching staff of the schools in collaboration with PEC professionals defined the procedures regarding the initial evaluation and the criteria for selecting students to whom the educational activities were addressed (Department Education, 1999), which followed the following order of priority:

One. Significant educational deficit and educational integration difficulties arising from family abandonment or marginalization.

Two. Ethnic or cultural minorities presenting a significant deficit at school (a difference of two or more years between the curriculum level and what should correspond according to chronological age), especially with respect to:

- Gypsy students with special support needs arising from late schooling and truancy.

- Immigrant students with special support needs arising from lack of knowledge of Catalan and/or Spanish or late inclusion to our educational system.

- Pupils at risk of abandoning the educational system, who, because of their social and family conditions present significant and generalized educational deficits (i.e. more than three years' difference).

Recently, the Compensatory Education Program promoted and advised the drafting of an overall reception plan designed for schools prioritizing (Alegre \& Herrera, 2000): the admission of students from families that have recently arrived, that of students starting school at a later age than normal, and that of large families. For example, these authors described the work in Mataró in two areas: the reception and monitoring of Maghreb children. The first task is the organization of their reception (show the school, the class, etc.) which is formally prepared by both the PEC and the corresponding teaching center; though it varies quite a lot if it follows an itinerary established by the Department of Education. As the latest novelties, if there is any kind of language difficulty, they may resort to the mediator (who, in reality, only acts as a translator who explains the necessary documentation for submission for the enrollment application, see Llevot, 2004). They also take into account issues regarding the type of religion followed by the family, if the child has been schooled before or not, etc. and the level of skills, determined by the Educational Psychology Assessment Team (EAP) with tests to ascertain their level of learning.

Secondly, subsequent monitoring is to ensure that students get integrated into regular activities for a period of one to two years. When there are cases that require a more thorough follow-up, because the student experiences a cultural contrast between what they are discovering and what the family provides, they can be referred to social services or groups of contact with the family. 
Another initiative that was also promoted consisted of the launch of regional educational resource centers dedicated to both the programming and coordination of criteria for action on the schools and the organization of work groups to develop specific materials (reception, fight against xenophobia, etc.).

In this line of support for diversity, Language Workshops for late inclusion were started in Osona during the year 1996-1997, specified in the Anselm Turmeda Project for teaching language to students from other cultures speaking other languages in order to facilitate their integration. This experience became integrated into the LIC (Language and Social Cohesion) area.

The aim was to provide schools with specific support in relation to the late inclusion of students into the education system through workshops and courses aimed directly at them in order to help them acquire a sufficient knowledge of the language to allow them to communicate with the immediate environment and continue learning in the school while giving them an introduction to the way of living of the country hosting them, and which, from the 1998-1999 academic year, brought about a new modality: school adaptation and basic instrumental learning workshops.

Overall, the Education Program for the 2000-2004 quadrennial (Department of Education, 2000) included a series of actions that arose from the principle of priority of support for students with special specific educational needs due to disadvantaged socio-economic and cultural situations. It adopted new concepts within the educational discourse in substitution for others: equality instead of that of equal opportunities for all, instituting the right of every person to enjoy opportunities matching their abilities; cohesion, replacing that of tolerance; and integration, which takes the place of compensatory action.

One of the actions that was prioritized was the control and reduction of absenteeism, with the collaboration of the schools and the local authorities to achieve its eradication.

Finally, summarizing the evolution of this program toward intercultural education (Besalú 2002, p. 147):

The first is derived from the assessments carried out: even in those experiences in which it has been possible to verify significant success upon completion of the program, its effects have not lasted long. We know that educational equality is not the main or direct route toward social equality. Therefore, to achieve this objective other measures are necessary, which directly attack the causes of social inequality. However, compensatory policies in schools, regardless of their contentious social effects, undoubtedly have positive effects on a personal level and are a sign of the concern of society for effective equal opportunities.

Clearly these timid actions were insufficient to meet the current needs of social and educational inclusion, and did not open a clear path for changing 
some schools' trend of social exclusion, so there are a number of important points listed below.

There is an alarming concentration of students at risk of marginalization in certain public schools, some of which have adhered to the call by the education authorities as preferred educational care centers. This attribution involves a series of grants related to the number of students per class, the provision of more support teachers, priority in the awarding of scholarships and financial aid, etc., to alleviate some of the students' basic needs (food, hygiene at home, school materials ...).

But what has not been done in these centers is create specific training programs for the professionals who work there or a monitoring committee, or an organization for coordination and exchange between them in order to promote some center projects and more effective curricular projects, depending on the population they have to attend to.

Nor is there any action that questions the disappearance of the school population with the greatest social expectations to schools in neighboring districts which enjoy greater social prestige. Thus, the policy on charters with the private school implies that the preferred educational support centers decrease their enrollments and become ghetto centers while private ones are expanding considerably with new enrollments and implementing building works. It so happens that at the same time and place in which there are too many public places or classes are reduced, charter schools are allowed to increase their student admissions.

In the last decrees governing registration for the period 2012-2013, it was proposed that all schools supported by public funds - charter schools included - had to reserve four places per classroom, which should be covered by the registration committee, to accommodate students with special educational needs or specific needs in terms of their social and family situation.

This was intended to alleviate the ghettoization of some schools and make them all part of the social reality around us. The result, however, has been that while private schools got at most these four students, public schools in the most run-down areas are still receiving, almost exclusively, all the other students with difficulties.

To this situation it should also be added that in the previous two decades, despite latent threats, the progress achieved by the normalization of the Catalan language and culture has been evident in schools through the application of language immersion programs. However, Catalan has not yet reached full or true standardization in the current social context, where its fragility is even more evident. 


\section{Transformation to the Plan FOR LANGUAGE AND SOCIAL COHESION (LIC)}

In view of the suggestions made in the proposals for improvement of the education system made by the National Conference on Education 20002002 (2002) within Section III on Support for Diversity, the Department of Education developed and initiated the Action Plan for Foreign Students 2003-2006 (PAANE). This plan dealt especially with aspects related to language learning and did not include enough basic aspects of reception, such as the emotional, cohabitational, relational and social cohesion that affect all students. For this reason, the Department drew up a new plan, which would again be framed in the Interdepartmental Immigration Plan, to consolidate the language as the backbone of an multilingual educational project and an intercultural educational model (Departament d'Ensenyament, 2013), in order to achieve social cohesion, the Plan for Language and Social Cohesion.

Given the new challenges posed by the reception and integration of newcomer students to the Catalan education system, the Subdirecció General de Llengua i Cohesió Social (Sub-directorate General of Language and Social Cohesion) was created by Decree 282/2004, within the Department of Education, aiming at ensuring equal opportunities for access to quality education, respecting cultural diversity and strengthening Catalan as crucial in a multilingual educational project based on the values of coexistence, equality, and educational and social inclusion of all students. The Sub-directorate General has two administrative units: the Catalan Teaching Service (SEDEC) and Interculturality and Social Cohesion Service (SICS) that, in coordination, will steer the plan in the regions, where there will be a team for support and advice on matters of language, interculturality and social cohesion.

One of the contributions of this plan is that intercultural education should not be seen as an issue that only affects those schools with students at risk of sociocultural marginalization but it must become a fundamental part of the curriculum for all students, as it highlights the need to work together to build a model of an open, democratic society that respects the rights of minorities. Accordingly, the general objective is to promote and strengthen social cohesion, intercultural education and the Catalan language in a multilingual framework.

Based on quantitative and qualitative data regarding the use of Catalan, the existence of students at risk of marginalization and social exclusion, the baseline conditions of schooling and the degree of integration of new students, the achievement of skills, among other things, it is expected to track the Plan in order to evaluate the effectiveness of actions and the degree of achievement of the objectives. Such monitoring and evaluation will be undertaken by the Education Inspectorate (in the Department of Education, 2004). 
Assessment indicators for the Plan (Department of Education, 2004) must be based on the following points, taking into account that they will have to be adjusted to conform them to the different social and personal circumstances of the students, school stage and cycle: time between arrival and schooling, rate of absenteeism, language proficiency (Catalan and Spanish), subject assessment results, basic skills test results, relational climate at the center, participation in complementary and extracurricular activities, the number of students studying post-compulsory education, and index of parental involvement in teaching activities. In order to evaluate the effectiveness of this plan, the authorities wish to enhance the performance of research that allows concrete and specific quantitative and qualitative analysis of the schools to improve actions and, when appropriate, plan new actions.

Some of the most innovative actions are the community plans as instruments to design a coordinated action for all students, placing special emphasis on newcomers and/or those at risk of sociocultural marginalization and promoting multiculturalism and social cohesion.

To this end, attempts are made to foster inclusion factors through lines of intervention that are summarized below (Department of Education, 2004): ensure the learning of Catalan as the backbone within the context of a multilingual society and adaptation to the basic cultural parameters of the Catalan society by students' families; promote the decentralization of students in the enrollment and registration process; train the different levels of the receiving educational community in intercultural and social skills; encourage family participation; promote coexistence and involvement in leisure activities; adjust the supply to the new needs and new interests; promote dialogue between all and strive for intercultural and citizenly attitudes.

\section{OPEN REFLECTIONS}

Cultural diversity is not a new phenomenon in schools, but there have been changes in the way it is considered. We have gone from models that postulated that integration in a society meant assimilating the culturally different (into the dominant group) to more up-to-date discourses of recognition and acceptance, to a greater or lesser extent, by the society and the school of "other cultures» (see Tarrow, 1990; Southwell \& Perry, 2011).

In Spain, the evolution witnessed in other societies is not foreign to us, although the pace and timing do not coincide. For Fernández Enguita (1996), historically three different stages can be distinguished in relation to support for diversity. Initially the «culturally different» (mostly gypsies) were 
simply excluded from the educational institution as well as other institutional and social spheres; this exclusion gave way to segregation since the so-called «bridging schools», despite their name, turned into a kind of nontemporary segregated schooling (see National Gypsy Secretariat, 1982); and third is inclusion into the regular classroom with the support of compensatory education programs (see Garreta 2003 and 2011).

Simultaneously, the aforementioned evolution coexisted with the passage of a centralized education system to a decentralized one in which the autonomous communities acquired a very important role (in some more than others) in education matters. This has led, for example, to different ways of understanding and working with cultural diversity (see CIDE, 2005).

In this last phase of inclusion and gradual recognition of cultural diversity in schools, the first small step was taken by the 1970 Education Law, which was established in the compensatory education law that was passed in 1983 (Royal Decree of April 27, 1983, BOE 05/11/1983) with the creation of a specific program to benefit the geographical areas or population groups whose special characteristics required preferential educational care.

The goals and actions this program was to carry out consisted mainly of the following: the creation of school support services, incentives for teaching staff sent to unattractive areas, the organization of professional training courses for out-of-school youths of fourteen and fifteen years of age, the eradication of illiteracy, the creation of study scholarships or grants ... The program does not consider the disappearance of inequalities as an immediate objective, but the development of a policy of equal opportunities leading gradually to the fact that educational outcomes are not determined by variables like living in rural areas or belonging to disadvantaged social classes (Samper, Garreta, \& Llevot, 2001).

The Compensatory Education Program, which developed students' rights to receive aid in order to compensate for possible shortcomings linked with family type, did not refer in its foundations to ethnicity or cultural diversity as a factor of inequality in the educational system, as it spoke of "compensatory and inclusive» projection of the education policy in relation to the disadvantaged due to their «economic capacity, social status or place of residence». However, the program did include the "cultural minorities» as a specific field of action oriented at the schooling of children, the regularization of attendance and the prevention of early abandonment (Terrén, 2001).

The Compensatory Education Program was changed slowly, its actions influenced by the demands of teachers, as well as the intercultural discourse that started to appear confusingly, especially in the late nineties. In summary, the aforementioned studies show a certain evolution in the nineties but still suggesting, with more or less force, that educational practice is more assimilatory and compensatory than intercultural per se. 
A previous study of ours (Garreta \& Llevot, 2003; Garreta, 2006), also indicates that the dynamics of implementation of intercultural education is slow and that in the absence of a general or specific proposal of how to translate the discourse into practice (teachers are not given sufficient guidance and resources and are forced to define before this issue and so act) its materialization does not seem easy in the short term despite the help of the LIC Plan. However, actions have been implemented (for example, see actions on mediation and promoting schooling among immigrants in Garreta, 2011b, gypsy population in Llevot $\&$ Bernad, 2016) to include students and families from minorities at risk.

In fact, the question must be asked as to whether there is a desire to put intercultural discourse (which is currently within the discourse on social cohesion) into practice (see last study on cultural and religious diversity by Llevot, en prensa). And if the existence in itself of pedagogical rhetoric ${ }^{10}$, often without resources, intervention strategies, etc., really is useful to students of foreign origin (understood in the same way as defined by the Catalan education authorities) and their families in order to improve their academic opportunities and of continuing in the education system.

This research article has received a grant for its linguistic revision from the Language Institute of the University of Lleida (2016 call).

\section{REFERENCES}

Alegre, M. A., \& Herrera, D. (2000). Escola, oci i joves d'origen magribi: el sentit de la inserció social de les segones generacions de famílies immigrades. El cas de Mataró. Barcelona: Diputació de Barcelona (Materials de Joventut, 14).

Benestar Social (1994). Pla Interdepartamental d'Immigració. Barcelona: Departament de Benestar Social - Generalitat de Catalunya.

Bernstein, B. (1971). Education cannot compensate for society. In B. R. Cosin et al., School and society (pp. 64-70). London: Routdledge - Open University.

Besalú, X. (2002). Diversidad cultural y educación. Madrid: Síntesis.

Carbonell, F. (1997). Immigrants estrangers a l'escola: desigualtat social i diversitat cultural en l'educació. Barcelona: Fundació Serveis de Cultura Popular - Editorial Altafulla.

10 The authorities' roadmap toward support for minorities can be seen in the Department of Education regulations (http://ensenyament.gencat.cat/ca/inici). In it we highlight all actions that are carried out with varying success: support for reception classrooms and centers, Immersion Plan, the centre's Language Project, Support for education plans of the surroundings, the schooling of students gypsy students, Actions related to the center's cohabitation project. 
Carbonell, F. (2000). Educació i immigració: els reptes educatius de la diversitat cultural i l'exclusió social. Barcelona: Fundació Jaume Bofill - Mediterrània (Collecció Polítiques, 27).

Centro de Investigación y Documentación Educativa - CIDE (1992). El sistema educativo español. Madrid: MEC.

Centro de Investigación y Documentación Educativa - CIDE (2005). La atención al alumnado inmigrante en el sistema educativo en España. Madrid: Ministerio de Educación y Ciencia.

Conferència Nacional d'Educació (2002). Debat sobre el sistema educatiu català: conclusions i propostes. Barcelona: Publicacions del Departament d'Ensenyament de la Generalitat de Catalunya.

Consell Escolar de Catalunya (1997). La diversitat a l'escola. Jornada de reflexió. Tortosa: Consell Escolar de Catalunya - Generalitat de Catalunya.

Crespo, R. (1997). Inmigración y escuela. In II Informe sobre inmigración y trabajo social (pp. 625-663). Barcelona: Diputació de Barcelona.

Departament d'Ensenyament (1988). Instruccions del Programa de Marginats Socials. Barcelona: Generalitat de Catalunya.

Departament d'Ensenyament (1996a). Educació intercultural: orientacions per al desplegament del curriculum. Barcelona: Generalitat de Catalunya.

Departament d'Ensenyament (1996b). 10 anys de programes educatius. Barcelona: Generalitat de Catalunya.

Departament d'Ensenyament (1999). Normativa: full de disposicions $i$ actes administratius. Barcelona: Generalitat de Catalunya.

Departament d'Ensenyament (2000). Educació 2000-2004. Barcelona: Generalitat de Catalunya.

Departament d'Educació (2004). Pla per a la Llengua i la Cohesió Social. Barcelona: Generalitat de Catalunya.

Departament d'Ensenyament (2007). Pla per a la Llengut i la Cohesió Social. Educació i convivència intercultural. Barcelona: Generalitat de Catalunya.

Departament d'Ensenyament (2013). Ofensiva del pais a favor de l'èxit escolar. Pla per a la Reducció del Fracàs Escolar a Catalunya 2012-2018. Barcelona: Generalitat de Catalunya.

Fernández Enguita, M. (1993). Redes económicas y desigualdades sociales. Revista Española de Investigaciones Sociológicas, 37, 41-79.

Fernández Enguita, M. (1996). Escuela y etnicidad. El caso del pueblo gitano. Granada: Laboratorio de Estudios Interculturales.

Garreta, J. (2003). La integración sociocultural de las minorías étnicas (inmigrantes y gitanos). Barcelona: Anthropos.

Garreta, J., \& Llevot, N. (2003). El espejismo intercultural. La escuela de Cataluña ante la diversidad cultural. Madrid: Centro de Investigación y Documentación Educativa. 
Garreta, J. (2006). Ethnic minorities in the Spanish and Catalan educational systems: From exclusion to intercultural education. International Journal of Intercultural Relations 30(2), 261-279.

Garreta, J. (2011a). La atención a la diversidad cultural en Cataluña: exclusión, segregación e interculturalidad. Revista de Educación, 355, 213-233.

Garreta, J. (2011b). Las experiencias escolares de la inmigración. Papers. Revista de Sociología, 96, 205-223.

Gomis, P. L. (1996). Guía práctica del Programa Sócrates 1995-2000. Madrid: CECECITE.

Grup FUS (1999). Educació i immigració extracomunitària. Barcelona: Grup FUS Fundació Serveis de Cultura Popular.

Jordán, J. A. (1992). L'educació multicultural. Barcelona: CEAC (XIII Premi Pallach d'Educació).

Llevot, N. (2004). Els mediadors interculturals a les institucions educatives de Catalunya. Lleida: Pagès.

Llevot, N. (2005). Del Programa d'Educació Compensatòria al nou Pla per a la Llengua i la Cohesió Social. Papers. Revista de Sociologia, 78, 197-214.

Llevot, N. et al. (en prensa). Diversità culturale e religiosa nei centri scolastici della Scuola Primaria in Catalogna. Rivista Civitas Educationis. Education, Politics, and Culture.

Llevot, N., \& Bernad, O. (2016). La mediación gitana: herramienta performativa de las relaciones entre escuela y familia. Revista Electrónica Interuniversitaria de Formación del Profesorado, 19, 99-110.

Martí, Q. (2008). El Pla per a la Llengua i la Cohesió Social (Pla LIC) i la seva concreció als centres educatius. Revista Guix. Monogràfic: Llengua, Interculturalitat $i$ Cohesió Social, 341, 9-13.

Montano, F., Castella, E., \& Pérez, P. (1992). El Programa d'Educació Compensatòria i les minories ètniques. In G. Puig (Coord.), Recerca i educació interculturals (pp. 203-215). Barcelona: La Llar del Llibre.

Muñoz Sedano, A. (1989). La escolarización de los niños gitanos e itinerantes en España. Madrid: Informe ante la Comisión de las Comunidades Europeas.

Palaudàrias, J. M. (1998). Educació i integració en el cas de la comunitat marroquina a Girona: una anàlisi entre el país d'origen i el pais d'assentament. Girona: Departament de Pedagogia. Facultat de Ciències de l'Educació.

Perry, L. B., \& Southwell, L. (2011). Developing intercultural understanding and skills: Models and approaches. Intercultural Education, 22(6), 453-466.

Programa d'Educació Compensatòria (1998). Memòria de final de curs 1997/1998. Lleida: PEC.

Programa d'Educació Compensatòria Tarragona/Lleida (1994). Minories ètniques $i$ escola. Espluga de Francolí: PEC (Document intern). 
Samper, L., Garreta, J., \& Llevot, N. (2001). Les enjeux de la diversité culturelle dans l'école catalane (Espagne). Revue des Sciences de l'Éducation de la Université de Montreal, 3, 543-568.

Samper, L., Llevot, N., Garreta, J., \& Chastenay, M. H. (2002). Éducation et ethnicité: le cas catalan. In M. Mc Andrew \& F. Gagnon, Relations ethniques et éducation dans les sociétés divisées (Québec, Irlande du Nord, Catalogne et Belgique) (pp. 127-147). París - Montreal: L'Harmattan.

Secretariado Nacional Gitano (1982). Escuela puente para niños gitanos. Madrid: Instituto de Sociología Aplicada.

Tarrow, N. (1990). A tri-level model of intercultural education in two regions of Spain. Frankfurt: Deutsches Institut für Internationale Pèdagogische Forschung.

Terrén, E. (2001). El contacto intercultural en la escuela. A Coruña: Servicio de Publicacións da Universidade da Coruña.

\section{Riassunto}

Questo articolo delinea il piano di sviluppo del Ministero della Pubblica Istruzione condotto attraverso il Programma Compensativo per l'Istruzione e si concentra sui cambiamenti registrati in Catalogna in base all'applicazione del Piano per la Lingua e la Coesione Sociale. Questo programma è stato il risultato emblematico della politica riformista adottata nel 1983 nel campo dell'istruzione. É stato, quindi, un progetto pieno di speranza e ottimismo mirato a correggere le diseguaglianze sociali e a produrre alti livelli di giustizia sociale. Nonostante le debolezze intrinseche che hanno caratterizzato questo approccio, il Programma sull'Istruzione ha consentito di effettuare interventi in zone particolarmente complesse e, inoltre, la gamma di attività svolte è stata molto ampia e ambiziosa. Attualmente, la sua trasformazione rappresenta una sfida per il governo che intende promuovere la formazione delle minoranze etniche a rischio di esclusione sociale, nonché sviluppare azioni volte a promuovere il successo scolastico, per ridurre il fenomeno dell'abbandono degli studi (prevista per il 2018). Il Progamma di Istruzione Compensativa è rivolto agli studenti di origine straniera al fine di migliorare le loro opportunità di studio per non uscire precocemente dal sistema di istruzione.

Keywords: Immigrati, Linguaggio e abbandono scolastico, Politica educativa, Progetto compensativo, Scuola.

How to cite this Paper: Llevot Calvet, N., González Rodríguez, J. A., \& Revilla Carrasco, A. (2016). The new plan for the prevention of school failure in Catalonia (Spain) [Il nuovo piano per la prevenzione dell'insuccesso scolastico in Catalogna (Spagna)]. Journal of Educational, Cultural and Psychological Studies, 13, 119-142. doi: 10.7358/ecps-2016-013-llev

\footnotetext{
ECPS Journal - 13/2016

http://www.ledonline.it/ECPS-Journal/
} 